\title{
Candida albicans \\ epididymo-orchitis and fungemia in a patient with chronic myelogenous leukemia
}

Mark Pimentel mD, Lindsay E Nicolle mD frCPC, SAlman Qureshi MD FRCPC

\begin{abstract}
M PIMENTEL, L NICOLLE, S QURESHI. Candida albicans epididymo-orchitis and fungemia in a patient with chronic myelogenous leukemia. Can J Infect Dis 1996;7(5):332-334. The fourth reported case of candidal epididymo-orchitis in the literature and the first reported case successfully cured with only low dose amphotericin B is described. A 75-yearold male with chronic myelogenous leukemia presented with acute testicular and epididymal swelling and pain. Subsequent investigations suggested the diagnosis of epididymo-orchitis due to Candida albicans. This was successfully treated with intravenous amphotericin B (total dose of $500 \mathrm{mg}$ ). Based on the three previous case reports and the current case several characteristic features that increased the suspicion of this entity were identified. These features include an immunocompromised state, candiduria, specific epididymal ultrasonographic appearance, as well as typical clinical features of epididymo-orchitis.
\end{abstract}

Key Words: Amphotericin B, Candida albicans, Epididymitis

\section{Épididymo-testiculite et infection fongique systémique chez un patient atteint de leucémie chronique myélogénique}

RÉSUMÉ : Le quatrième cas d'épididymo-testiculite rapporté dans la littérature et le premier cas de guérison avec seulement de faibles doses d'amphotéricine B est décrit. Un homme âgé de 75 ans atteint de leucémie chronique myélogénique s'ést présenté avec une enflure testiculaire et épididymale aigües et de la douleur. L'examen subséquent a suggéré le diagnostic d'épididymo-testiculite causée par Candida albicans. It fut traité avec succès par administration intraveineuse d'amphotéricine B (dose totale de $500 \mathrm{mg}$ ). En se basant sur trois cas rapportés précédemment dans la littérature ainsi que sur celui-ci, plusieurs caractéristiques communes suggérant cette condition ont été identifiées. Ces caractéristiques comprennent un état d'immunosuppression, une candidurie, un aspect ultrasonique spécifique de l'épididyme, ainsi que les caractéristiques cliniques spécifiques à l'épididymo-testiculite.

E pididymitis due to fungi is rare. It is primarily a bacterial disease. In older men Gram-negative bacilli are the most frequent pathogens, while sexually transmitted pathogens such as Chlamydia trachomatis, Ureaplasma urealyticum or
Neisseria gonorrhoeae predominate in younger groups (1). The increasing population of immunocompromised hosts has generated a third etiological category due to opportunistic pathogens. Recent reports describing epididymitis in organ

Department of Medicine and the Division of Infectious Diseases, The University of Manitoba, and Health Sciences Centre, Winnipeg, Manitoba

Correspondence and reprints: Dr S Qureshi, L11-144 Montreal General Hospital, 1650 Cedar Avenue, Montreal, Quebec H3G 1A4. Telephone 514-937-6011, fax 514-934-8261, e-mail cxqu@musica.mcgill.ca 
transplant patients and those infected with human immunodeficiency virus (HIV) 1 have reported infection with Nocardia asteroides (2), cytomegalovirus (3) and Haemophilus influenzae (4). There have been only three previous case reports of epididymo-orchitis caused by Candida albicans in the literature (5-7). Two of the cases reported were treated with azoles $(5,6)$ and the other was treated with a combination of orchiectomy and bladder instillation of amphotericin B (7). We report the first case of candidal epididymo-orchitis successfully treated with intravenous amphotericin B alone.

\section{CASE PRESENTATION}

A 75-year-old male had stable chronic myelogenous leukemia of two years' duration maintained on oral chlorambucil. He was admitted to hospital with a history of mild, nonbloody diarrhea and subacute diffuse abdominal pain of three to four days' duration. Three months earlier a transurethral resection of the prostate gland for benign hypertrophy had been performed. No fungi were isolated from his urine at that time. There was no other history of genitourinary abnormalities.

Physical examination was remarkable for fever, diffuse abdominal tenderness with voluntary guarding and an exquisitely tender, enlarged $(6 \times 10 \mathrm{~cm})$ left testicle and epididymis with overlying scrotal edema. A rectal examination was not performed due to severe perineal pain.

Initial laboratory results included a neutrophil count of 8300 cells $/ \mathrm{mm}^{3}$ and a creatinine level of $520 \mu \mathrm{mol} / \mathrm{L}$. The urinalysis showed hematuria, pyuria and moderate proteinuria. An abdominal ultrasound revealed bilateral ureteric dilation. Intravenous pyelography showed right hydronephrosis, a possible right ureteric calculus and another stone in the left renal pelvis. There was no evidence of a fungal 'ball' on imaging. Blood and urine cultures were obtained and the patient was treated initially with intravenous cloxacillin and gentamicin. Within $48 \mathrm{~h}$ these were replaced with cefazolin because of the potential renal toxicity of gentamicin.

The patient subsequently underwent lithotripsy for stone dissolution with placement of bilateral ureteric stents to relieve obstruction. Analysis of stone fragments showed uric acid but microbial cultures were not obtained. The patient's renal function improved following the insertion of ureteric stents; however, his scrotal pain and fever persisted. A scrotal ultrasound demonstrated marked scrotal wall thickening as well as several small hypoechoic lesions of the left epididymis. Gross enlargement of the left testicle was seen without clear evidence of an infiltrative process.

On day five, urine cultures taken on admission grew $\mathrm{C}$ albicans greater than $10^{8}$ colony forming units/L, and simultaneous blood cultures were positive for $\mathrm{C}$ albicans. Consequently, the cefazolin was discontinued and intravenous amphotericin B was started at $35 \mathrm{mg}$ daily and continued to a total dose of $500 \mathrm{mg}$. The patient's abdominal symptoms, scrotal swelling and erythema clearly improved with the initiation of antifungal therapy and were virtually resolved within one week. At discharge, the serum creatinine was $121 \mu \mathrm{mol} / \mathrm{L}$ and the left testicle and epididymis were nontender and of normal size.
Clinical examination, cystoscopy and retrograde pyelography one month later were normal. The patient remained asymptomatic six months after this admission but required ongoing management of the leukemia.

\section{DISCUSSION}

Until recently, epididymitis due to $\mathrm{C}$ albicans was unrecognized. To our knowledge, only three other cases have been reported in the literature. The first report described a HIV 1 seropositive patient who presented with unilateral scrotal pain and swelling associated with pyuria (5). Cure was achieved with a six-week course of oral ketoconazole. The other two cases occurred in diabetic men with urethral instrumentation and urinary tract colonization with $\mathrm{C}$ albicans. One of these (6) was cured with six weeks of oral fluconazole, 200 mg daily. Surgical exploration, unilateral orchiectomy and bladder instillation of amphotericin B were used to effect a cure in the third case (7). In this case, the diagnosis of invasive fungal epididymitis was confirmed by operative cultures and histological examination of excised tissue.

Predisposing factors for infection in our patient included malignancy, immunosuppressive therapy, urolithiasis and ureteric obstruction with previous urological surgery. Fungal colonization of the urine likely preceded the transurethral prostatic resection and the operative procedure promoted invasive disease.

The sonographic findings considered to be most reliable in epididymal inflammation include thickening of the scrotal wall combined with epididymal enlargement (8). In this case, scrotal ultrasound was useful to confirm epididymal inflammation and exclude an associated abscess.

Based on an extensive review of the literature, this is the first case of epididymo-orchitis successfully treated with low dose intravenous amphotericin B alone. The treatment appeared very effective with no long term sequelae or relapse. Fluconazole is known to have greater urinary excretion (9) than ketoconazole, but in two of the previous cases of orchitis $(5,6)$, both fluconazole and ketoconazole had equal efficacy at six weeks. This suggests that, although urinary colonization and instrumentation may predispose patients to epididymoorchititis, cure of established disease requires use of antifungal agents with good tissue penetration rather than simple eradication of the organism in the urine. Both fluconazole and ketoconazole may provide this coverage.

In summary, candidal epididymo-orchitis is a very rare entity with features characteristic of other forms of epididymitis. In the present case and three other reported cases, scrotal ultrasound helped confirm the characteristic local inflammatory changes. In addition, the isolation of $\mathrm{C}$ albicans from the urine culture prompted consideration of this organism as the epididymal pathogen in this immunocompromised host. We are not aware of any clinical criteria that reliably differentiates opportunistic causes of epididymitis from those caused by conventional bacterial agents or sexually transmitted pathogens. In the immunocompromised patient, other rarer causes of epididymo-orchitis must be considered in patients who fail to respond to usual therapy, and appropriate cultures should be obtained. 


\section{REFERENCES}

1. Melekos MD, Asbach HW. Epididymitis: Aspects concerning etiology and treatment. J Urol 1987;138:83-6.

2. Wheeler JS, Culkin DJ, O'Connel J, Winters G. Nocardia epididymo-orchitis in an immunosuppressed patient. J Urol 1986;136:1314-5.

3. McCarthy JM, McLoughlin MG, Shackleton CR, et al. Cytomegalovirus epididymitis following renal transplant. J Urol 1991;146:417-9.

4. Cross JT, Davidson KW, Bradsher RW. Hemophilus influenzae epididymo-orchitis and bacteremia in a man infected with the human immunodeficiency virus. Clin Infect Dis 1994;19:768-9.
5. Swartz DA, Harrington P, Wilcox R. Candida epididymitis treated with ketoconazole. N Engl J Med 1988;319:1485.

6. Gordon DL, Maddern J. Treatment of candida epidiymo-orchitis with oral fluconazole. Med J Aust 1992;156:744.

7. Docimo SG, Rukstalis DB, Rukstalis MR, Kang J, Cotton D, DeWolf W. Candida epididymitis: Newly recognized opportunistic infection. Urology 1993;41:280-2.

8. Jafri SZH, Bree RL, Madrazo BL, Loginsky S. Sonography of large scrotal infections. J Clin Ultrasound 1991;19:413-8.

9. Brammer KW, Farrow PR, Faulkner JK. Pharmacokinetics and tissue penetration of fluconazole in humans. Rev Infect Dis 1990:12(Suppl 3):S318-26. 


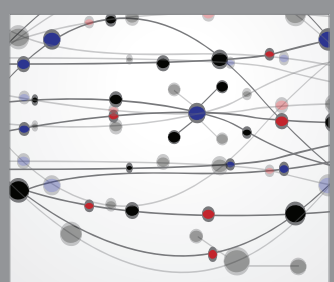

The Scientific World Journal
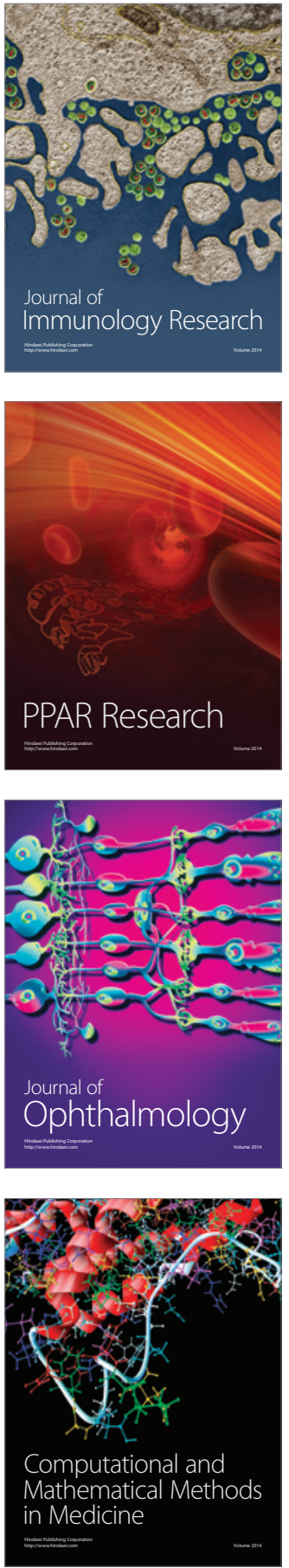

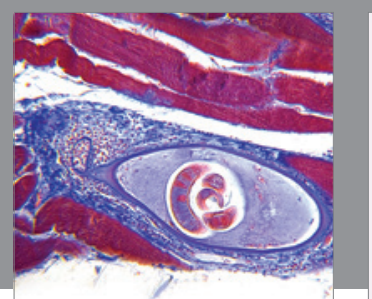

Gastroenterology Research and Practice

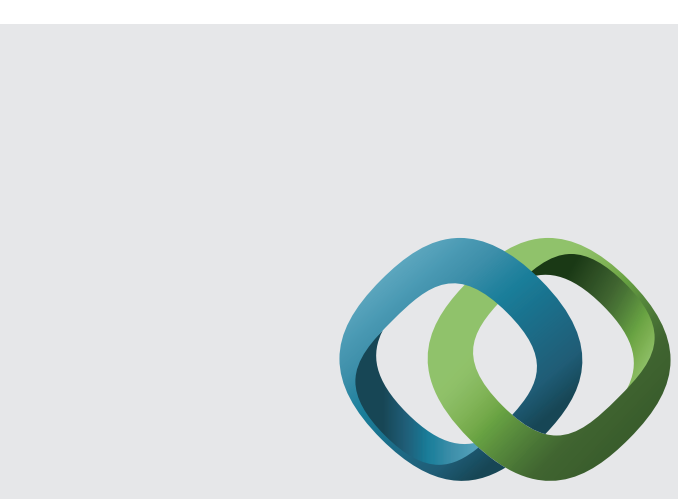

\section{Hindawi}

Submit your manuscripts at

http://www.hindawi.com
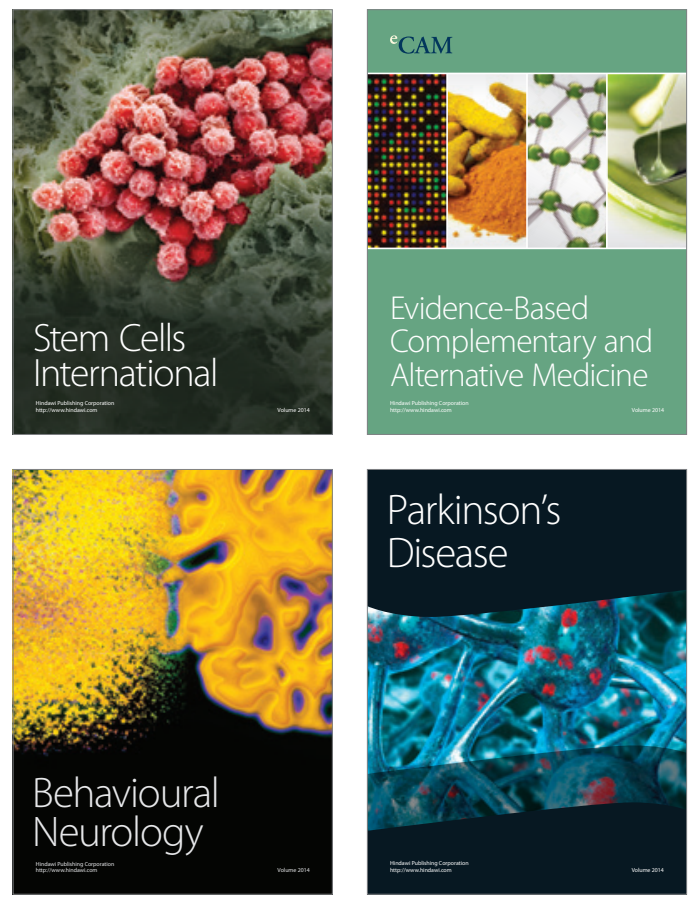
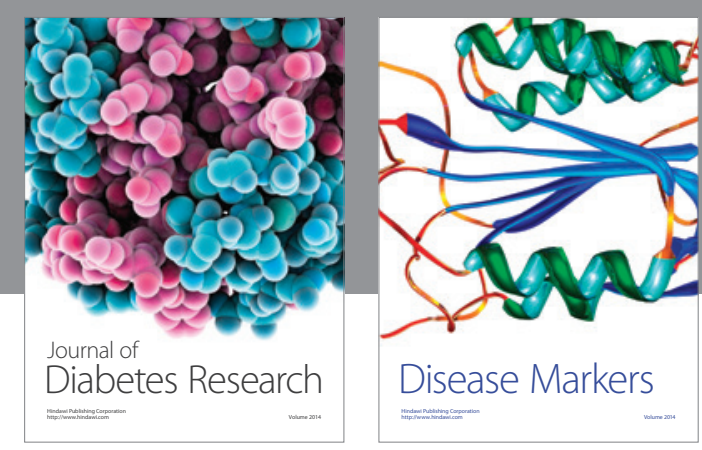

Disease Markers
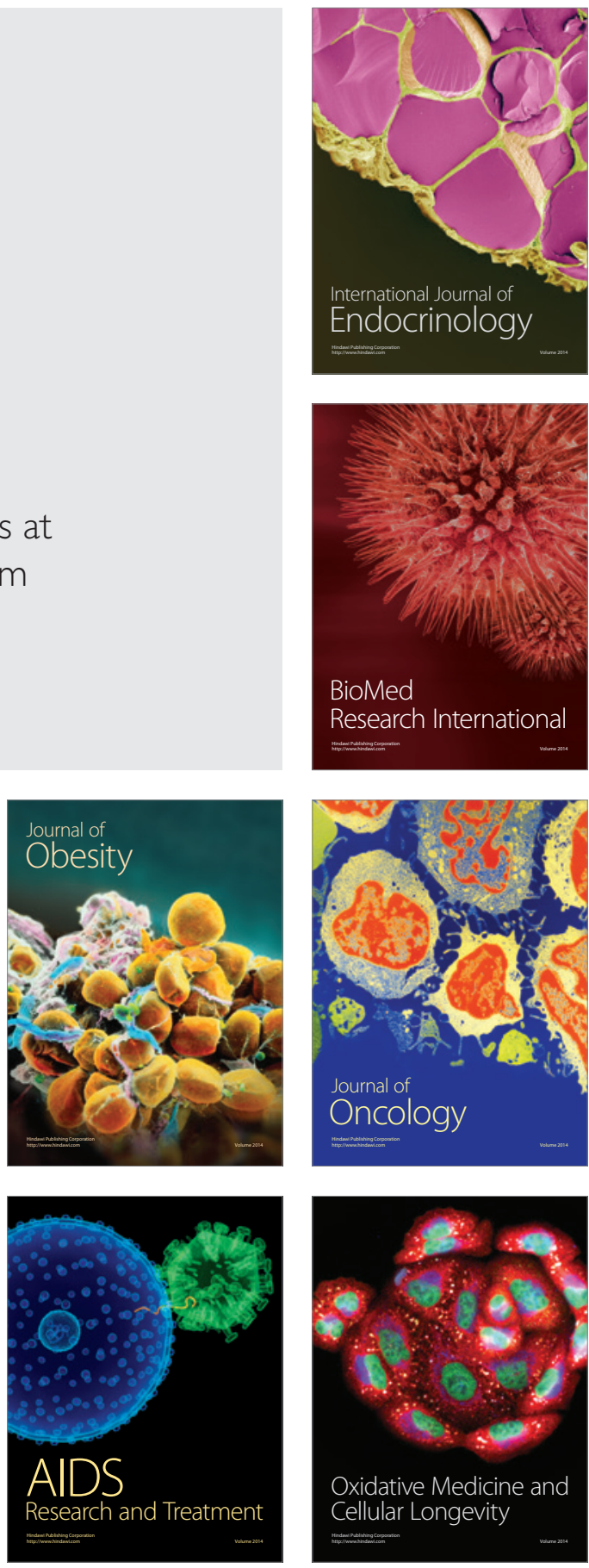